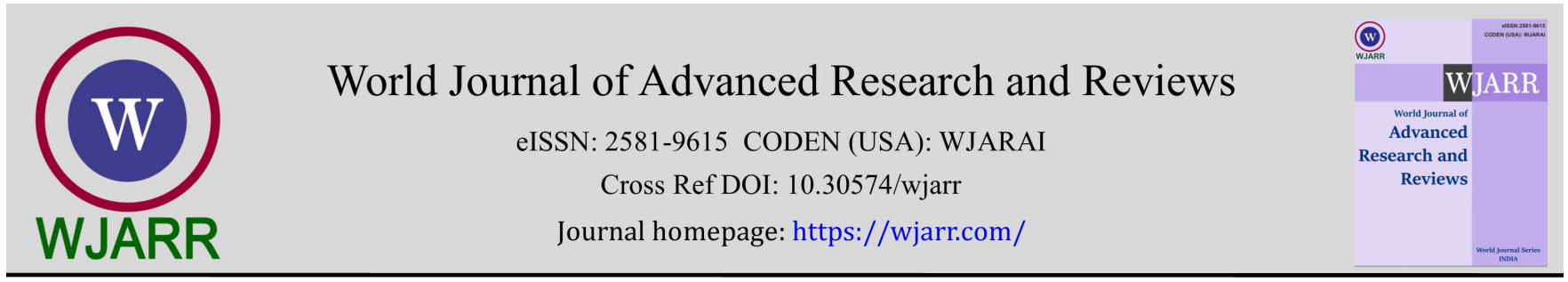

(RESEARCH ARTicle)

\title{
Phytochemistry and antioxidant activity of Amaranthus viridis L (Green leaf)
}

\author{
Ezekwe Ahamefula Sunday *, Wokocha Peter Gift and Woha James Boobondah \\ Department of Medical Biochemistry, College of Medical Sciences, Rivers State University, Nkpolu Oroworukwo, Port \\ Harcourt, Nigeria.
}

World Journal of Advanced Research and Reviews, 2021, 12(02), 306-314

Publication history: Received on 18 September 2021; revised on 07 November 2021; accepted on 09 November 2021

Article DOI: https://doi.org/10.30574/wjarr.2021.12.2.0468

\begin{abstract}
Phytochemistry and antioxidant activity of Amaranthus viridis L (Green leaf) were undertaken with standard methods. The leaf sample after being screening for phytochemicals, contained tannins, saponins, flavonoids, alkaloids, steroids, phenolic compounds, proteins and anthraquinones at different concentrations. A further study using Gas Chromatography-Mass Spectrophotometry (GC-MS) analytic method on the leaf sample revealed a total of twenty-two detailed compounds among which are 3-Hydroxy-N-methylphenethylamine, Erucic acid, n-Hexadecanoic acid, 1,2Propanediol,3-chloro-, and Cystamine. 3-Hydroxy-N-methylphenethy lamine had the highest retention time; Erucic acid had the highest molecular weight while n-Hexadecanoic acid had the highest peal area. Most of the compounds have important applications in body care products and cosmetics, pharmaceutical or food industries. A. viridis leaf extract exhibited a better antioxidant activity against the ascorbic acid used as control in the present study. The phytochemicals present in the leaf sample could be behind its antioxidant activity. The study has shown the phytochemistry and antioxidant activity of $A$. viridis leaf sample.
\end{abstract}

Keywords: Antioxidant activity; Amaranthus viridis; Phytochemistry; GC-MS analysis

\section{Introduction}

Leafy vegetables have played crucial roles in complementing diets for humans and animals [1-7]. Edible vegetables are embodiment of nutritional materials for the body. Vegetables also contribute significant fiber to human diet. In recent years, studies have shown that fiber has the capacity to lower cholesterol and also strengthen the passage of bowels through the body. Apart from the contributions of vegetables in the nutrition of humans and animals, they are also employed in traditional medicine [8-14]. They are among the major raw materials of traditional medicine practice [1533]. Different authors have defined traditional medicine in different perspectives. However, each perspective inculcated the use of medicinal plants as core raw materials [15, 17, 20, 25, 29-30, 34-37]. Studies have revealed the ameliorative potential of some vegetables against some disease conditions [20, 25, 38-39]. It has been reported that these vegetables contain bioactive compounds which are physiologically active against disease causing pathogens [35-41]. These compounds have been collectively known as phytochemicals [15, 28, 34-37]. Further details on phytochemicals have revealed molecules that possess the potential to ameliorate, cure or prevent some disease conditions [35-43]. It has also been reported that some of the phytochemical molecules form the basis for modern pharmacopeia as synthesized model of compounds [44].

Amaranthus viridis L. popularly called green in Nigeria, which belongs to Amaranthaceae family is among the vegetables employed in traditional medicine. It is distributed in the warmer climates of the world [8, 10, 32]. The plant is believed to have originated from Asia but it is sometimes addressed as a cosmopolitan weed found in temperate as well as

${ }^{*}$ Corresponding author: Ezekwe Ahamefula Sunday

Department of Medical Biochemistry, College of Medical Sciences, Rivers State University, Nkpolu Oroworukwo, Port Harcourt, Nigeria.

Copyright (C) 2021 Author(s) retain the copyright of this article. This article is published under the terms of the Creative Commons Attribution Liscense 4.0. 
tropical and subtropical part of the world [8, 32-33]. In African, A. viridis is cultivated deliberately for use [8, 10-11, 33] and can also be found as weed [33]. The plant is described as ascending annual or short-lived perennial herb that grows up to $1 \mathrm{~m}$ tall. It has alternate leaves which possess petiole and can grow up to $10 \mathrm{~cm}[8,32]$. The leaves of $A$. viridis are glabrous and have light green lower surface and dark green upper surface. Lessen of $A$. viridis is used against labour pain and as antipyretic [15, 34]. The leaves of the plant are used against rashes, psoriasis, and eczema. The fruits, leaves, and flowers of $A$. viridis serve as vermifuge in veneral diseases, antiulcer, analgestic, laxative, as an antileprotic, as antiinflammatory agents of urinary tract, against high blood sugar as well as against high cholesterol [35-37].

Studies have revealed that some leafy vegetables are also effective in facilitating the molecules that act as body defense mechanisms $[14,45]$. These molecules are called antioxidants and they counter the activities of reactive oxygen species [45-46]. Excessive production of reactive oxygen species against antioxidants results in a condition known as oxidative stress. Oxidative stress has been recognized as the root of most generative diseases of the body [45-48]. Antioxidants that act as defense mechanisms are major cellular redox buffers ascorbate and glutathione ( $\gamma$-glutamyl-cysteinylglycine, GSH) as well as tocopherol, carotenoids, and phenolic compounds; and enzymatic components such as superoxide dismutase, catalase, guaiacol peroxidase, enzymes of ascorbate-glutathione cycle ascorbate peroxidase, monodehydroascorbate reductase, dehydroascorbate reductase, and glutathione reductase [47-49].

This study investigated the detailed phytochemistry and antioxidant activity of $A$. viridis L using its leaf sample.

\section{Material and methods}

\subsection{Sample Collection and Identification}

Leaves of $A$. viridis used for the present study were harvested from the plant in Imo State University School Farm and identified by a Botanist in the Department of Plant Science and Biotechnology, Imo State University, Owerri, Nigeria. They were washed, dried in the sun for few weeks before they were milled and stored for further studies.

\subsection{Preparation of Extract}

The method as described by Ezekwe et al. [50] was used in the preparation of aqueous extract. Ten grams of the milled sample was extracted by maceration in $50 \mathrm{~mL}$ of water for three days with frequent agitation at a speed of $280 \mathrm{rpm}$ at $28^{\circ} \mathrm{C}$ in the dark. The sample was then centrifuged for 10 minutes at $2000 \mathrm{rpm}$. The combined supernatants were collected, filtered through Whatman No 1 filter paper and was then concentrated. The concentrate was placed in a vacuum desiccator for complete removal of solvent. The yield extract was thus used for some of phytochemical screening, gas chromatography-mass spectrophotometry (GC-MS) analysis and assessment of antioxidant activity.

\subsection{Qualitative phytochemical Screening}

Tannins, phlobatannins, alkaloids, saponins, flavonoids, steroids, terpernoids, cardiac glycosides, phenolic componunds, proteins, redcing sugars, and anthraquinnones were screened on the leaf extract.

\subsection{Test for tannin}

The method as described by Amadi et al. [51] was used for the screening tannins. Two millilitres (2 mL) of extract was mixed with an equal volume of bromine water. The formation of greenish to red precipitates was taken as positive result for the presence of tannins.

\subsection{Test for phlobatannins}

The method as described by Amadi et al. [51] was used for the phytochemical screening of phlobatannins. Five millilitres $(5 \mathrm{~mL})$ of the extract was added to $2.0 \mathrm{~mL}$ of $1 \%$ Hydrochloric acid ( $\mathrm{HCl})$, and red precipitate was then as evidence for the presence of phlobotannins.

\subsection{Test for saponins}

The method as described by Amadi et al. [51] was used for the screening of saponins. Two drops of olive oil was added to $1 \mathrm{~mL}$ of the extract and shaken vigorously. The formation of emulsion was taken as positive result for saponins. 


\subsection{Test for flavonoids}

The method as described by Amadi et al. [51] was used for the screening of flavonoids. One millilitre (1 mL) of the extract was mixed with an equal volume of sodium hydroxide $(\mathrm{NaOH})$ and shaken properly. The formation of precipitate was taken as positive result for flavonoids.

\subsection{Test for alkaloids}

The method as described by Amadi et al. [51] was used for the screening of alkaloids. One millilitre of extract was shaken with $5 \mathrm{~mL}$ of $2 \%$ hydrochloric acid on a steam bath and was the filtered. The filtrate was then treated with Meyer`s reagent. A cream coloured precipitate was taken as positive result for alkaloids.

\subsection{Test for steroid}

Salkowski test was used for the screening of steriods. $1 \mathrm{~mL}$ of the extract was dissolved in $2.0 \mathrm{~mL}$ of chloroform in a test tube. Through one side of the test tube, $1 \mathrm{~mL}$ of concentrated $\mathrm{H}_{2} \mathrm{SO}_{4}$ was carefully added. A reddish brown colour at the interphase was taken as positive test for steroid nucleus.

\subsection{Test for terpenoids}

One gram of seed sample was shaken in a test tube with $10 \mathrm{~mL}$ of methanol, and then filtered. $5 \mathrm{~mL}$ extract was then mixed with $2 \mathrm{~mL}$ of chloroform and $3 \mathrm{~mL}$ of sulphuric acid was added. Formation of reddish brown color indicates the presence of terpenoids in the selected plants.

\subsection{Cardiac glycosides}

Half gram of sample was dissolved in $1.0 \mathrm{~mL}$ pyridine. 5 drops of $2 \%$ sodium nitroprusside and 3 drops of $20 \% \mathrm{NaOH}$ were added. The presence of deep red colour which fades to brown yellow was taken as positive result for cardiac glycosides.

\subsection{Test for phenolic compounds}

Phloroglucinol test was used.One percent of $\mathrm{FeCl}_{3}$ was added to $2 \mathrm{~mL}$ of the extract and the presence of blue, violet, purple, green or red-brown colour was taken as positive result for phenolic compounds.

\subsection{Test for proteins}

Four millilitres of the extract was mixed with $5.0 \mathrm{~mL}$ of distilled water and was allowed to stay for 3 hours, and was then boiled. $2 \mathrm{~mL}$ of the boiled extract was then added to $01 \mathrm{~mL}$ of million`s reagent and shaken vigorously. A pinkish precipitate was taken as positive test for protein.

\subsection{Test for anthroquinones}

One gram of the extract was placed in a dry test tube and $20 \mathrm{~mL}$ of chloroform was added. This was heated in steam bath for $5 \mathrm{~min}$. The extract was filtered while hot and allowed to cool. $2 \mathrm{~mL}$ of the filtrate was nixed with equal volume of $10 \%$ ammonia solution and shaken vigorously. The presence of brick pink colouration was taken as positive result for anthraquinones.

\subsection{Gas Chromatography-Mass Spectrophotometry (GC-MS) Analysis of the Extracts}

The method as described by Ezekwe et al. [50] was for GC-MS. GC-MS analysis of the aqueous extracts was carried out using AOC-20i auto sampler and gas chromatograph interface to a mass spectrometer (GC-MS) instrument. Employing the following conditions; column Elite- 1 fused silica capillary column (30 mm $\times 0.25 \mathrm{~mm} \mathrm{ID} \times 1 \mu \mathrm{M} \mathrm{df}$, composed of $100 \%$ Dimethyl poly siloxane), operating in electron impact mode at $70 \mathrm{eV}$; helium (99.999\%) was used as carrier gas at a constant flow of $1 \mathrm{ml} / \mathrm{min}$, and an injection volume of $0.5 \mu \mathrm{l}$, Split ratio of $10: 1)$, with injector temperature $250^{\circ} \mathrm{C}$; and ion-source temperature $280^{\circ} \mathrm{C}$. The oven temperature was programmed from $110^{\circ} \mathrm{C}$ (Isothermal for $2 \mathrm{~min}$ ), with an increase of $10^{\circ} \mathrm{C} / \mathrm{min}$ to $200^{\circ} \mathrm{C}$, then $5^{\circ} \mathrm{C} / \mathrm{min}$ to $280^{\circ} \mathrm{C}$, ending with a 9 mins isothermal at $280^{\circ} \mathrm{C}$. Mass spectra were taken at $70 \mathrm{eV}$; a scan interval of 0.5 seconds and fragments from 45 to $450 \mathrm{Da}$. Total GC running time was 36 mins. The plant extract was dissolved in aqueous and filtered with polymeric solid phase extraction (SPE) column and analyzed in GC-MS for different components.Interpretation of mass spectrum GC-MS was conducted using the database of National Institute Standard and Technology (NIST) having more than 62000 patterns. The spectrum of the unknowncomponents was compared with the spectrum of the known components stored in the NIST library. The name, molecular weight and structure of the components of the test were ascertained. 


\subsection{Determination of Antioxidant Activity}

DPPH (1, 1-Dipheny 1-2-picrylhydrazyl) radical scavenging assay: This was carried out with the method of BrandWilliams et al. [52], following the procedure as described by Ezekwe et al. [50]. The free radical scavenging activity was measured by DPPH assay method. Four mg of DPPH $(0.1 \mathrm{mM})$ was dissolved in $100 \mathrm{~mL}$ of distill water to obtain working solution. One mL of each extract was mixed separately with $2.0 \mathrm{~mL}$ of $0.1 \mathrm{mM}$ DPPH followed by 30 min incubation in dark. The reduction of the DPPH free radical was measured by taking the absorbance at $517 \mathrm{~nm}$. Colour of DPPH was reduced from purple to yellow. The antioxidant activity of each extracts was evaluated by calculating the inhibition $\%$ of free radical formation using the formula:

$\%$ inhibition $=\left[\left(A-A_{1}\right) / A\right] \times 100 ; A=$ absorbance of the blank $(D P P H) ; A 1=$ absorbance of the extract $(D P P H+$ extract $)$.

\section{Results and discussion}

Table 1 Phytochemical screening of $A$. viridis leaf extract

\begin{tabular}{l|l|c|}
\hline Phytochemicals & Status \\
\hline Tannins & ++ \\
\hline Phlobatannins & - \\
\hline Saponins & ++ \\
\hline Flavonoids & + \\
\hline Alkaloids & + \\
\hline Steroids & + \\
\hline Terpenoids & - \\
\hline Cardiac glycosides & - \\
\hline Phenolic compounds & + \\
\hline Proteins & + \\
\hline Reducing sugars & -- \\
\hline Anthraquinones & + \\
\hline
\end{tabular}

Phytochemicals screened in the presents study include tannins, phlobatannins, saponins, flavonoids, alkaloids, steroids, terpenoids, cardiac glycosides, phenolic compounds, proteins, reducing sugars and anthraquinones. From Table 1, the concentrations of tannins and saponins were high, while the concentrations of flavonoids, alkaloids, steroids, phenolic compounds, proteins and anthraquinones were low. Phlobatannins, terpenoids, cardiac glycosides, and reducing sugars were not found in $A$. viridis leaf extract. The phytoactivity and physiological effects of some of these phytochemicals have been reported by different authors. Tannins have been reported to possess anti-inflammatory, antioxidant, analgesic as well as wound healing properties [53-54]. Saponins are known to possess bitter taste, and are foamy in nature [55]. Saponins have reported to possess antibacterial properties [55-56]. Dietary flavonoids have been reported to oppose coronary heart disease [57]. Alkaloids possess reductive effect towards fever and headache [55]. They also possess analgesic and antibacterial properties. Steroids form the nucleus of all the steroid hormones and are involved as precursors to those hormones. The insecticidal property of most phenolic compounds has been reported by different authors.The role of proteins in body building and energy generation has been reported [12]. Proteins also serve precursor for growth of microorganisms [58]. Anthraquinones are known to repel birds. They are also useful in pulp, textile and dye industries $[54,58]$.

A more detailed study of the compounds found in A.viridis leaf extract using GC-MS analysis (Table 2), revealed a total of twenty-two compounds with their retention time, molecular formula, molecular weight, and peak areas (as shown in the Chromatograph of Figure 1). 3-Hydroxy-N-methylphenethylamine had the highest retention time; Erucic acid had the highest molecular weight while n-Hexadecanoic acid had the highest peal area. Some of these compounds are particularly important when their uses and effects in the biological system are considered. 1,2-Propanediol, 3-chlorois an industrial important compound used in chemical productions. It could also irritate the mucous membrane, skin and eye. The compound is suspected to be a human carcinogenic compound. Cystamine is a tranglutaminases inhibitor and a symmetric organodisulphide [59]. It has a radioprotective effect and displays synergistic effects in combination with cysteine [60-61]. Paul and Snyder [62] reported the therapeutic application of Cysteamine and Cystamine in 
neurodegenerative and neuropsychiatric diseases. 8-Nonen-2-one is a class of flavoring agent. Hexadecanoic acid methyl ester has applications in food, syrups and perfume industries. n-Hexadecanoic acid is among the fatty acids that can be found naturally in both plants and animals. It can also be created artificially in the laboratory. It has wide application in personal care products and cosmetics. Phytol is a diterpenoid natural compound with pharmacological applications [63]. It is a chlorophyll component with anti-inflammatory and metabolic properties. Phytol also has a remedy effect on the central nervous system [63]. Tetradecanoic acid has surfactant properties and is applied the beauty and cosmetic industries. cis-11-Eicosenoic acid has engine, pharmaceutical and cosmetic applications. Erucic acid is a monounsaturated omega-9 fatty acid, which could result in a heart problem called myocardial lipidosis, over on long exposure.

Antioxidant studies as presented in Figure 2, showed percentage inhibitions of the $A$. viridis leaf extract taken at 10, 20, 30 and $40 \mathrm{mg} / \mathrm{L}$ concentrations as $4.98 \%, 18.44 \%, 25.01 \%$, and $444.26 \%$. These inhibitions were against $1.12 \%$, $15.73 \%, 23.60 \%$ and $40.45 \%$ observed for the ascorbic acid used as control. In generality, $A$. viridis leaf exhibited better antioxidant activity than the control in the present study and could possess antioxidant potential. Plants with antioxidant activity have been reported by different authors [14, 64].

Table 2 GC-MS of A.viridis leaf extract

\begin{tabular}{|c|c|c|c|c|c|}
\hline $\mathbf{S} / \mathbf{N}$ & RT & Name of Compound & $\begin{array}{l}\text { Molecular } \\
\text { Formula }\end{array}$ & MW & $\begin{array}{c}\text { Peak } \\
\text { Area \% }\end{array}$ \\
\hline 1 & 2.435 & 1,2-Propanediol, 3-chloro- & $\mathrm{C}_{3} \mathrm{H}_{7} \mathrm{ClO}_{2}$ & 110 & 4.84 \\
\hline 2 & 2.611 & N-Dimethylaminomethyl-N-methylformamide & $\mathrm{C}_{5} \mathrm{H}_{12} \mathrm{~N}_{2} \mathrm{O}$ & 116 & 0.85 \\
\hline 3 & 3.820 & Cystamine & $\mathrm{C}_{4} \mathrm{H}_{12} \mathrm{~N}_{2} \mathrm{~S}_{2}$ & 152 & 2.80 \\
\hline 4 & 4.510 & Benzeneethanamine & $\mathrm{C}_{8} \mathrm{H}_{11} \mathrm{~N}$ & 121 & 2.02 \\
\hline 5 & 5.339 & Cyclobutane, methylene- & $\mathrm{C}_{5} \mathrm{H}_{8}$ & 68 & 1.21 \\
\hline 6 & 8.019 & $\begin{array}{l}\text { Spirio-10-(2,11-dioxabicyclo [4.4.1]undeca-3,5- } \\
\text { diene)-2'-(oxirane), 1,3,7,7-tetramethyl- }\end{array}$ & $\mathrm{C}_{14} \mathrm{H}_{20} \mathrm{O}_{3}$ & 236 & 1.18 \\
\hline 7 & 8.548 & 2,2'-Thiodisuccinic acid & $\mathrm{C}_{8} \mathrm{H}_{10} \mathrm{O}_{8} \mathrm{~S}$ & 266 & 1.49 \\
\hline 8 & 9.013 & Bicyclo [3.1.1] heptane, 2,6,6-trimethyl-, $(1 \alpha, 2 \beta, 5 \alpha)$ - & $\mathrm{C}_{10} \mathrm{H}_{18}$ & 138 & 5.03 \\
\hline 9 & 9.062 & 8-Nonen-2-one & $\mathrm{C}_{9} \mathrm{H}_{16} \mathrm{O}$ & 140 & 1.54 \\
\hline 10 & 9.308 & Oxirane, hexadecyl- & $\mathrm{C}_{18} \mathrm{H}_{36} \mathrm{O}$ & 268 & 2.04 \\
\hline 11 & 9.629 & Hexadecanoic acid, methyl ester & $\mathrm{C}_{17} \mathrm{H}_{34} \mathrm{O}_{2}$ & 270 & 2.00 \\
\hline 12 & 9.805 & 2,2'-Thiodisuccinic acid & $\mathrm{C}_{8} \mathrm{H}_{10} \mathrm{O}_{8} \mathrm{~S}$ & 266 & 1.81 \\
\hline 13 & 9.982 & n-Hexadecanoic acid & $\mathrm{C}_{16} \mathrm{H}_{32} \mathrm{O}_{2}$ & 256 & 26.95 \\
\hline 14 & 10.752 & 9,12,15-Octadecatrienoic acid, methyl ester, (Z,Z,Z)- & $\mathrm{C}_{19} \mathrm{H}_{32} \mathrm{O}_{2}$ & 292 & 1.60 \\
\hline 15 & 10.827 & Phytol & $\mathrm{C}_{20} \mathrm{H}_{40} \mathrm{O}$ & 296 & 11.80 \\
\hline 16 & 11.078 & $9,12,15$-Octadecatrienal & $\mathrm{C}_{18} \mathrm{H}_{30} \mathrm{O}$ & 262 & 20.04 \\
\hline 17 & 11.196 & Tetradecanoic acid & $\mathrm{C}_{14} \mathrm{H}_{28} \mathrm{O}_{2}$ & 228 & 4.68 \\
\hline 18 & 12.217 & cis-11-Eicosenoic acid & $\mathrm{C}_{20} \mathrm{H}_{38} \mathrm{O}_{2}$ & 310 & 2.64 \\
\hline 19 & 12.351 & Adipamide & $\mathrm{C}_{6} \mathrm{H}_{12} \mathrm{~N}_{2} \mathrm{O}_{2}$ & 144 & 0.92 \\
\hline 20 & 13.030 & cis-10-Nonadecenoic acid & $\mathrm{C}_{19} \mathrm{H}_{36} \mathrm{O}_{2}$ & 296 & 0.87 \\
\hline 21 & 13.282 & Erucic acid & $\mathrm{C}_{22} \mathrm{H}_{42} \mathrm{O}_{2}$ & 338 & 2.82 \\
\hline 22 & 19.080 & 3-Hydroxy-N-methylphenethylamine & $\mathrm{C}_{9} \mathrm{H}_{13} \mathrm{NO}$ & 151 & 0.82 \\
\hline
\end{tabular}




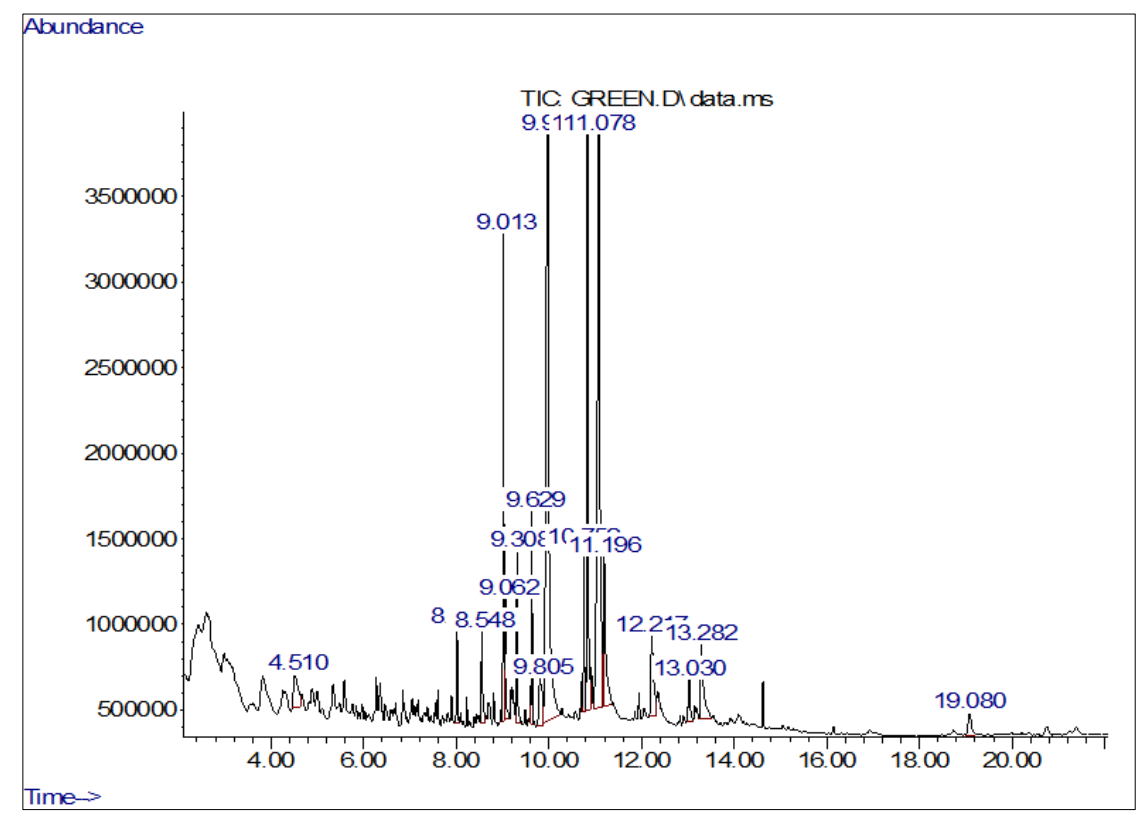

Figure 1 Chromatograph for $A$. viridisleaf extract

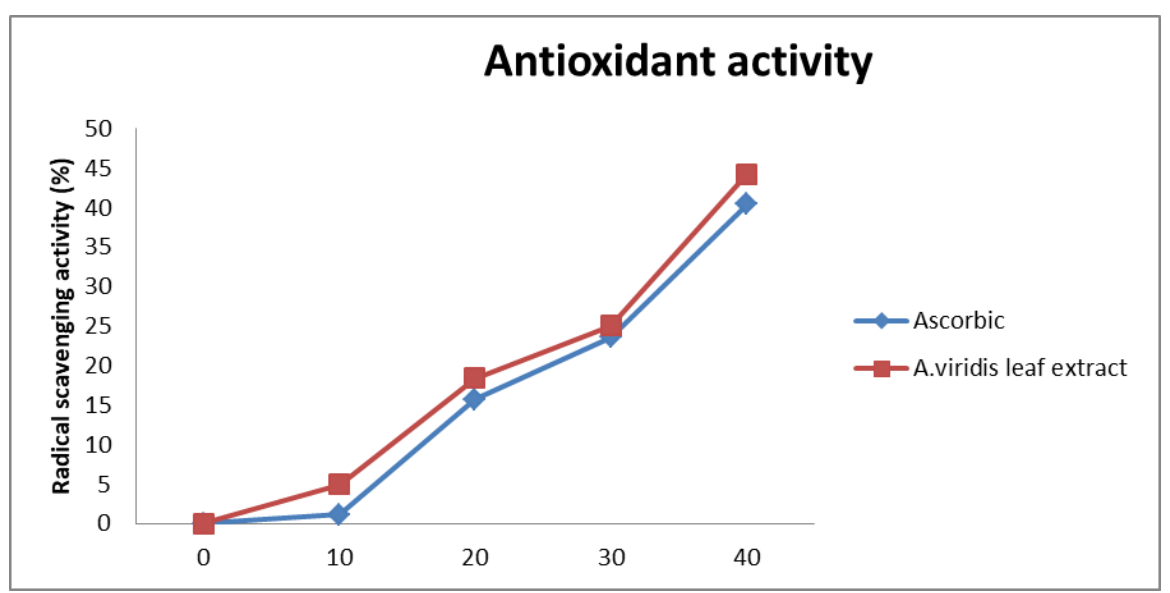

Figure 2 Antioxidant activity of A.viridis leaf extract

\section{Conclusion}

This study has shown that $A$. viridis leaf contain tannins, saponins, flavonoids, alkaloids, steroids, phenolic compounds, proteins and anthraquinones at different concentrations with about twenty-two detailed compounds revealed by further studies through GC-MS. The leaf sample also exhibited better antioxidant potential against the ascorbic acid used as the control in this present study. This study has revealed the phytochemistry and antioxidant activity of $A$. viridis $\mathrm{L}$.

\section{Compliance with ethical standards}

\section{Acknowledgments}

We acknowledge the efforts of all those who contributed toward making this work a success.

\section{Disclosure of conflict of interest}

There is no such as conflict of interest with regards to this work. All the authors are aware that the work has been sent to World Journal of Advanced Research and Reviews, and they all gave their consent to it. 


\section{References}

[1] Amadi B, Onuoha N, Amadi C, Ugbogu A, Duru M. Elemental, amino acid and phytochemical constituents of fruits of three different species of eggplants. International Journal of Medicinal and Aromatic Plants. 2013; 3(2): 200202 .

[2] Duru M, Amadi C, Ugbogu A, Eze A, Amadi B. Phytochemical, vitamin and proximate composition of Dacryodes edulis fruit at different stages of maturation.Asian Journal of Plant Science and Research. 2012; 2(4): $437-441$.

[3] Amadi B, Duru M, Agomuo E, Amadi P, Onedibe O. Nutritional, phytochemical and sensory evaluation of "Mberiagworagwo" traditional food of Uruagunnewi people in Anambra State, Nigeria. Journal of Advances in Biology \& Biotechnology. 2017; 14(1): 1-8.

[4] Duru M, Amadi C, Ugbogu A, Eze A, Amadi B. Phytochemical, vitamin and proximate composition of Dacryodes edulis fruit at different stages of maturation. Asian Journal of Plant Science and Research. 2012; 2(4): $437-441$.

[5] DuruMKC, Agomuo EA, Amadi BA. Nutrient composition of "Nduduagworagwo", a traditional food of Akokwa people in Ideato North L.G.A of Imo State, Nigeria. Continental J. Food Science and Technology. 2012; 6(3): 2732.

[6] Duru M, Amadi B, Eze A, Ugbogu A. Evaluation of "mgbam" traditional food on haematological profile and some selected biochemical parameters following consumption. Elixir Food Science. 2013; 64: 19345-19349.

[7] Amadi B, Agomuo E, Duru M, Anyanwu E, Onyeabo C, OdikaP. Amino acid profiles, anutinutrients, concentrations, of minerals and antinutrient-mineral molar ratios of "akidiagworagwo" and "nwagbaraoti" traditional foods. Polish Journal of Natural Sciences. 2020; 35(1): 57-74.

[8] Kirtikar KR, Basu BD. Indian Medicinal Plants. Dehra Dun, India : International book distributors. 1987; 3: 20612062.

[9] Townsend CC. Amaranthaceae. In: Polhill, R.M. (Editor). Flora of Tropical East Africa. A.A. Balkema, Rotterdam, Netherlands. 1985;136.

[10] Paulpati S, Babu SB, Nanasu ML. Phytochemcal and pharmacological potential of Amaranthus viridis L. International Journal of Phytomedicine. 2014; 6: 3222-326.

[11] Aju PC, Popoola L. Trees in the traditional farming system in Southeastern Nigeria. A case study of Imo State. J. Environ. Ext. 2005; 5: 25-31.

[12] Duru MKC, Arukwe U, Amadi BA. Bioactive constituents and macronutrients composition of anti-malarial concoction used in Umunchi village in Isiala Mbano L.G.A of Imo State, Nigeria. International Science Research Journal. 2011; 3: 61-64.

[13] Nwachukwu MI, Duru MKC, Nwachukwu IO, Obasi CC, Uzoechi AU, Ezenwa CM, Anumodu CK. In-vitro phytochemical characterization and antibacterial activity of Newbouldia laevis (boundary tree) on Escherichia coli and Staphylococcus aureus. Asian Journal of Microbiology and Biotechnology. 2017; 2(1): 30-36.

[14] Ezekwe AS, Nwadike CN, Wokocha GP, George BO. Phytochemical screening, GC-MS analysis and antioxidant activity of Curcurbita pepo L. using its leaf sample". Asian Journal of Biology. 2021; 11(4): 33-45.

[15] BurkillHM. The useful plants of West tropical African, Vol. 1. Royal Botanic Graden, Kew. 1985.

[16] Monago-Ighorodje C, Duru M, Adindu E, Nwauche K, Ezekwe A, Nosiri I, Odika P, Onyeabo C, OgarI,Berezi EP,UgohAI, Eboagwu I, OttaE. Effect of ethanolic leaf extract of Vinca major L. on biochemical parameters and glucose level of alloxan induced diabetic rats". African Journal of Biotechnology. 2019; 18(32): 1054-1068.

[17] Okwu DE. Phytochemicals and vitamin content of indigenous species of South Eastern Nigeria. J. Sustain. Agric Environ. 2004; 6: 30-34.

[18] Nwachukwu MI, Duru MKC, Amadi BA, Nwachukwu IO. Comparative evaluation of phytoconstituents, antibacterial activities and proximate contents of fresh, oven-dried uncooked and cooked samples of Buchholzia coriacea seed and their effects on hepatocellular integrity". International Journal of Pharmaceutical Science Invention. 2014; 3(6): 41-4.

[19] Duru M, Amadi B, Ugbogu AE, Okezie E, Uche-Ikonne C, Duru M, AtasieOC. Toxicity Evaluation of the aqueous stem extracts of Senna alata in wistar rats. American Journal of Biomedical Research. 2016; 4(4): 80-86. 
[20] Duru M, Amadi B, Ugbogu A, Eze A. Effect of "udu" an antimalarial herbal preparation on visceral organ weight and blood lipid profiles in wistar rats. Journal of Pharmacy and Clinical Sciences. 2014; 8: 1-7.

[21] Nwachukwu MI, Duru MKC, Nwachukwu IO.Antifungal properties and effect of fresh, oven dried uncooked and cooked seeds of Buchholzia coriacea on haematology and kidney.Elixir Food Science. 2013; 64: 19350-19356.

[22] Duru MKC, Amadi BA, Eze AE, UgboguAE, OnuohaN. In vivo studies of Solanum aethiopicum fruit on some biochemical parameters using rats". Journal of Chemical and Pharmaceutical Research. 2013; 5(2): 1-4.

[23] Amadi BA, Agomuo EN, Duru MKC. Toxicological studies of Asmina triloba leave on haematology, liver, kidney using rat model. International Science Research Journal.2013; 4(2): 11-17.

[24] Duru M, Ugbogu A, Amadi B. Effect of Solanum macrocarpon fruit on haematology, hepatic and renal function". Advances in Biochemistry. 2013; 1(2): 28-32.

[25] Duru MKC, Agomuo EN, Amadi BA.Biochemical studies on 'Udu' an antimalarial concoction used in Umunchi village, Isiala Mbano L.G.A of Imo State, Nigeria. Continental Journal of Pharmacology and Toxicology Research. 2012;5(2): 28-34.

[26] Amadi BA, Arukwe U, Duru MKC,Amadi CT, Adindu EA, Egejuru L, Odika PC. Phytonutrients and antinutrients screening of D.edulis fruits at different maturation stages. J. Nat. Prod. Plant Resour. 2012; 2(4): 530-533.

[27] Morebise 0,Fafunso MA, Makinde JM, OlajideOA, Awe EO. Anti-inflammatory property of Gongronema latifolium. Phytother. 2002; 16(l).

[28] Okwu DE. Phytochemicals, vitamins and mineral contents of two Nigerian medicinal plants". Int. J. Mol. Adv. Sci. $2005 ; 1(4): 375-381$.

[29] Amadi BA, Arukwe U, DuruMKC,Adindu EA,UfornwaEC,OdikaPC. The effect of fermentation on anti-nutrients, carbohydrates and vitamin contents of Pentaclethra macrophylla seed. International Science Research Journal. 2013; 3: 4-77.

[30] DuruM, NwadikeC, EzekweA, NwaogwugwuC, EboagwuI,Odika P,Njoku S, ChukwudoruoC.Evaluation of nutritional, anti-nutritional and some biochemical studies on Pleurotus squarrosulus (Mont.) singer using rats. African Journal of Biochemistry Research. 2018; 12(2): 7-27.

[31] Duru M, EboagwuI,KaluW, Odika P. Nutritional, anti-nutritional and biochemical studies on the oyster mushroom. Pleurotus ostreatus. EC Nutrition. 2019; 14(1): 36-59.

[32] Brenan JPM. The genus Amaranthus in southern Africa. Journal of South African Botany. 1981; 47: 451-492.

[33] Khan M, Musharaf S, Ibrar M, Hussain F. Pharmacognostic evaluation of the Amaranthus viridis L. Research in Pharmaceutical Biotechnology. 2011; 3(1):11-16.

[34] Gill LS. Ethnomedical uses of plants in Nigeria. University of Benin Press, Nigeria. 1992; 215.

[35] Ross IA. Medicinal plants of the world, Chemical Constituents, Traditional and Modern Uses. Humane Press, Totowa NJ 07512. 2001; 2: 487.

[36] Burkill HM. The useful plants of West Tropical Africa. 2nd Edition. Families J-L. Royal Botanic Gardens, Kew, Richmond, United Kingdom. 1995; 3: 857.

[37] Iwu MM. Handbook of African medicinal plants, 1st edition, CRC press Inc, Florida. 1993; 239-239.

[38] Agomuo EN, Duru MKC, Amadi BA. Some bioactive constituents of Asmina triloba (paw paw variety). International Science Research Journal. 2013; 4(2): 18-22.

[39] Duru M, Amadi B, Agomuo E, Eze A. Chemical profile of an anti-malarial concoction "Udu" used in Umunchi autonomous community in Isiala Mbano L.G.A of Imo State, Nigeria. Journal of Emerging Trends in Engineering and Applied Sciences (JETEAS). 2012; 3(3): 444-447.

[40] Duru M, Ugbogu A, Amadi B, Odika P, Chima-Ezika R, Anudike J, OsuochaK.Chemical constituents of Buchholzia coriacea seed. Proceedings of the 35th Annual International Conference, Workshop \& Exhibition of Chemical Society of Nigeria. 2012; $2: 39-45$.

[41] Amadi BA, Duru MKC, Agomuo EN. The chemical profiles of leaf, stem, and flower of Ageratum conyzoides. Asian Journal of Plant Sciences and Research. 2(4): 428-43.

[42] Duru MKC, Amadi BA, Amad CT, Lele KC, Anudike JC, Chima-Ezika OR, Osuocha K. Toxic effect of carica papaya bark on body weight, haematology and some biochemical parameters. Biokemistri. 2012; 24(2): 67-71. 
[43] Okoroh PN, Duru MKC, Onuoha SC, Amadi BA. Proximate composition, phytochemical and mineral analysis of the fruit of Ficus capensis. International Journal of Innovative Research and Development. 2019; 8(8): 84-88.

[44] Agomuo E, Duru M,Amadi B, Amadi P, Ugwokaegbe P. Effect of caffeine on some selected biochemical parameters using rat model". Advances in Biology. 2017;8.

[45] Noctor G, Foyer CH. Ascorbate and glutathione: Keeping active oxygen under control”. Annual Review of Plant Biology. 1998; 49: 249-279.

[46] Sulekha M, Satish Y, SunitaY, RajeshN. Antioxidants: A review. Journal of Chemical and Pharmaceutical Research. 2009; 1(1):102-104.

[47] Ugochukwu NH, Babady NE. Antioxidant effects of Gongronema latifolium in hepatocytes insulin dependent diabetes mellitus. Filoterapia. 2002; 73(7): 612-618.

[48] Nwanjo HU, Okafor MC, Oze GO. Anti-lipid peroxidative activity of Gongronema latifolium In Strptozotocininduced diabetic rats. Nig. J. Physiol. Sci. 2006; 21(1): 61-65.

[49] Duru MKC, Akubugwo EI, ChinyereGC, Alisa CO, Nwaogwugwu JC. Effect of seasonal water fluctuation of a water body on antioxidant activity of selected plants of lower phylum (A case study of Nche stream)" Academic Journal of Chemistry. 2018; 8: 2519-7045.

[50] Ezekwe AS, Ordu KS, Oruamabo RS. Phytochemical screening, GC-MS analysis and antioxidant activity of three medicinal plants from Nigeria. Asian Journal of Applied Chemistry Research. 2020; 6(3): 14-26.

[51] Amadi BA, Agomuo EN, Ibegbulem CO. Research methods in Biochemistry. Tonyben publishers.2004; 93-99.

[52] Brand-Williams W, Cuvelier ME, Barset C. Use of free radical method to evaluate antioxidant activity. LWT-Food Science and Technology. 1995; 28(1): 25-30.

[53] Ayinde BA, Omogbai EK, Amaechina FC. Pharmacognosy and hypotensive evaluation of Ficus exasperata Vahl (Moraceae) leaf. Acta Pol Pharm. 2007; 64: 543-546.

[54] Okwu DE, Okwu ME. Chemical composition of Spondias mombin Linn. Plants parts. J Sust Agric Environ. 2006; 6: 140-147.

[55] Adeoti TK, Oyedapo 0. Biochemical effects of saponins isolated from Momordica charantia. Med Chem \& Drug Disc. 2012;3: 65-70.

[56] Wadood A, Ghufran M, Jamal SB, Naeem M, Khan A, et al. Phytochemical analysis of medicinal plants occurring in Local Area of Mardan. Biochem Anal Biochem. 2013;2: 144.

[57] Pietta PG. Flavonoids as antioxidants. J Nat Prod. 2000;63: 1035-1042.

[58] Nwachukwu MI, Duru MKC, Nwachukwu IO.Microbial physiology and metabolism. Milestone Publishers Limited, Nigeria. 2015.

[59] Thomas MJ, John TP, Arthur JLC. Cystamine and cysteamine as inbitors of transglutaminase activity in vivo. Bioscience Report. 31(5).

[60] Bacq ZM, Dechamps G, Fischer P, Herve A, Le Bihan H, Lecomte J, et al. Protection against x-rays and therapy of radiation sickness with beta-mercaptoethylamine. Science. 1953; 117: 633-6.

[61] Straube RL, Patt HM. Studies with cysteinamine and cysteine in x-irradiated animals”. Proc Soc Exp Biol Med. 1953; 84: 702-4.

[62] Paul BD, Synder SH. Therapeutic applications of cysteamine and cystamine in neurodegenerative and neuropsychiatric diseases". MINI review article. Front. Neurol.December 2019; 12.

[63] Jessica PC, Johanssy S0, Luis MRJ, Revelison MF. Phytol a natural diterpenoid with pharmacological applications on central nervous system: A review. Recent Patents on Biotechnology. 2014; 8(3): 195-205.

[64] Ezekwe AS, Ordu KO, Oruamabo RS. Phytochemical screening, GC-MS analysis and antioxidant activity of three medicinal plants from Nigeria. Asian Journal of Applied Chemistry Research. 2020; 6(3):14-26. 